\title{
SALMONELLA/SHIGELLA/VIBRIO IN TREATED EFFLUENTS AND IMPACT ON DOWNSTREAM WATER USERS (SOUTH AFRICA)
}

\author{
Ilunga Kamika \\ University of South Africa \\ Pretoria, South Africa
}

\section{Timothy Sibanda}

University of Namibia

Windhoek, Namibia

\section{Maggy Momba}

Tshwane University of Technology South Africa

Pretoria, South Africa 


\section{Copyright: \\ (c) (i) (2) \\ BY SA}

This publication is available in Open Access under the Attribution-ShareAlike 3.0 IGO (CC-BY-SA 3.0 IGO) license (http://creativecommons.org/licenses/by-sa/3.0/igo). By using the content of this publication, the users accept to be bound by the terms of use of the UNESCO Open Access Repository (http://www.unesco.org/openaccess/terms-use-ccbysa-en).

\section{Disclaimer:}

The designations employed and the presentation of material throughout this publication do not imply the expression of any opinion whatsoever on the part of UNESCO concerning the legal status of any country, territory, city or area or of its authorities, or concerning the delimitation of its frontiers or boundaries. The ideas and opinions expressed in this publication are those of the authors; they are not necessarily those of UNESCO and do not commit the Organization.

\section{Citation:}

Kamika, I., Sibanda, T. and Momba, M. (2019). Salmonella/Shigella/Vibrio in treated effluents and impact on downstream water users (South Africa). In: J.B. Rose and B. Jiménez-Cisneros, (eds) Water and Sanitation for the 21st Century: Health and Microbiological Aspects of Excreta and Wastewater Management (Global Water Pathogen Project). (S. Petterson and G. Medema (eds) Part 5: Case Studies), Michigan State University, E. Lansing, MI, UNESCO. https://doi.org/10.14321/waterpathogens.73

Acknowledgements: K.R.L. Young, Project Design editor; Website Design: Agroknow (http://www.agroknow.com) 


\section{Summary}

\section{Highlights}

- Water sources impacted with inadequately treated wastewater harbour faecal pathogens

- Waterborne pathogens are responsible for 25 - 75\% of all diarrhoea in Africa

- We showed that current wastewater treatment practices do not yield safe effluents

- New management approaches (e.g. incentivising local authorities) at all levels are needed

- Strict enforcement of municipal bylaws will ensure compliance to set standards

\section{Risk Management Objective}

This case study reports the health risks faced by communities relying on untreated surface water contaminated by enteric bacterial pathogens for domestic, recreational and agricultural purposes in developing countries such as South Africa. Unless people have access to basic services such as safe drinking water and improved sanitation infrastructures, efforts to prevent death due to waterborne pathogens are doomed to fail.

\section{Location and Setting}

The study involved two wastewater treatment plants (WWTPs) in Sedibeng District, Gauteng South; and another two WWTPs located in the Soshanguve peri-urban area of Tshwane Local Municipality, Gauteng North, in South Africa. The Leeuwkuil WWTP and the Meyerton WWTP (both in Sedibeng District) were assessed because they are frequently hydraulically overloaded during the wet season, though their operational capacities remain manageable during the dry weather. It is believed that their operational inefficiencies pose pollution problems to receiving water bodies. The Rietgat and Sandspruit WWTPs serve the Soshanguve peri-urban area of the Tshwane Metropolitan Municipality and discharge their effluents into Sout Spruit River and Sun Spruit Rivers, respectively. These WWTPs were assessed because they have been showing an increasing risk trend when measured against the wastewater treatment works risk-rating criteria set by the Department of Water Affairs, South Africa.

Figure 1: Maps depicting sampling sites in Sedibeng District and Soshanguve peri-urban area of Tshwane Metropolitan Municipality, South Africa (Image reproduced with permission of RightsLink/Springer Nature)

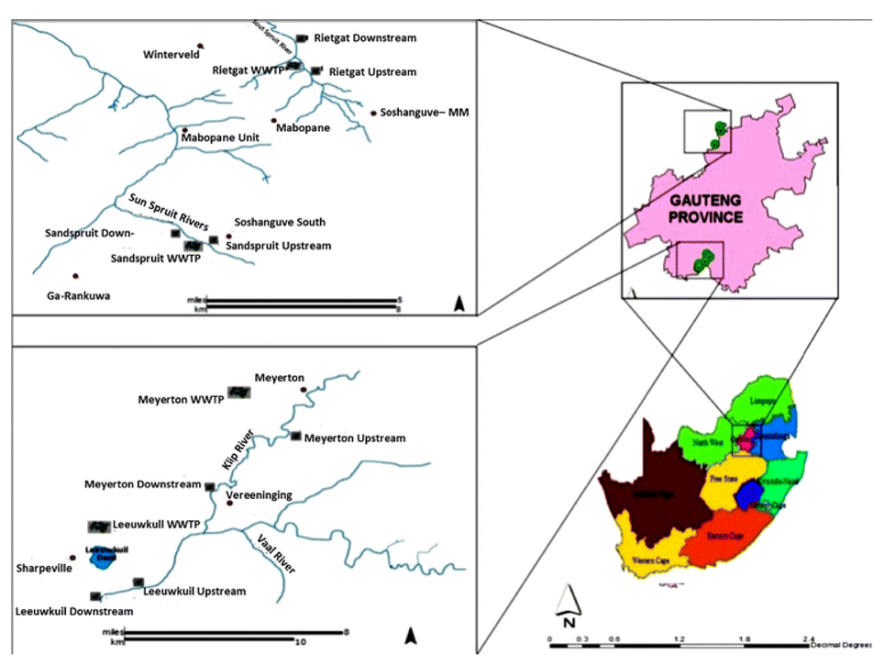

\section{Description of the System}

Sedibeng District is situated on the banks of the Vaal River and the Vaal Dam and has a population of 805 168. Of this, Meyerton and Leeuwkuil WWTPs serve approximately $83.13 \%$ and $23.5 \%$ of the households respectively. The Soshanguve peri-urban area has a population of 664900 , which is served by Rietgat and Sandspruit WWTPs, both of which have a design capacity of $20 \mathrm{M} \square /$ day. Currently, the water and sanitation backlog of the City of Tshwane Municipality comprises 69987 households and Soshanguve contributes $13.93 \%$.

\section{Outcome and Recommendations}

Based on the occurrence of bacterial pathogens in these water sources, and the volumes of raw water that can be ingested intentionally or accidentally, the daily combined risk of infection from S. typhimurium, S. dysenteriae and V. cholerae indicated that individuals who rely on these water sources for their daily needs run the risk of contracting $\mathrm{S}$. typhimurium, S. dysenteriae and V. cholerae infection after a single exposure. Quantitative microbial risk assessment (QMRA) provided a better assessment of water safety than the absence/presence of faecal indicators. It also helped to better understand the risks associated with different categories of water use, even if that water is from the same source.

Additional Treatment. The WWTPs hydraulic performance could be improved by upgrading their treatment capacity. Also, for domestic purposes, people could alternative treatment options like chlorine tablets and/or boiling in order to remove pathogens.

Restrictive Measures. Contact recreational activities in river pools should not be allowed until there is an improvement in the treatment efficiency of the WWTPs discharging into those rivers.

Want to read more? The full paper can be found here 


\section{References}

